\title{
Enhancing Science Process Skills Acquisition in Chemistry among Secondary School Students through Context-Based Learning
}

\author{
P. Okafor Ngozi* \\ Department of Science and Technology Education, Faculty of Education, University of Lagos, Nigeria \\ *Corresponding Author: nokafor@unilag.edu.ng
}

\section{ABSTRACT}

The study examined the effect of context-based learning (CBL) and gender influence on chemistry students' acquisition of integrated science process skills (ISPS). Two research questions guided the study. This study used a quasi-experimental research design with a sample of 192 participants who had an average age of 15 . Three instruments were used in data collection. Data were analyzed using mean and standard deviation. The results showed that CBL had more effect on students' ISPS in chemistry. Students exposed to CBL pedagogy acquired more Experimental Skill (EXPS) than Analyzing and Interpreting Data Skill (ANIDS) with Identifying and Controlling Variables Skill (ICVS) the least. Furthermore, students exposed to Conventional Strategy excelled in ANIDS, more so than ICVS with EXPS the least acquired. The influence of gender on ISPS was observed in favor of females. The study concluded that gender imbalance exists in all spheres of life; therefore, chemistry teachers should help students in acquiring integrated science skills using the two approaches to enhance male and female students' knowledge, values, and skills creatively in secondary school chemistry. The study recommends the teaching of students on everyday activities that foster gender balance in Lagos State secondary schools.

KEY WORDS: Context-based learning; Chemistry education; Integrated skills; Conventional strategy; Gender

\section{INTRODUCTION}

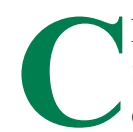
hemistry is one of the science subjects taught in the Senior Secondary Schools (SSS) and its curriculum content has some abstract concepts central to the learning of other science subjects (Okafor, 2017). Some students view chemistry as being disconnected from the realities of life (Okafor, 2017; Bennett et al., 2007). Several researchers have suggested the use of innovative pedagogies that can foster secondary school students' acquisition of problem solving and basic science process skills in chemistry (Okafor, 2018; Ojo, 2017). Majekodunmi (2007) and Okafor (2012) explained that knowledge of chemistry should be built on a solid foundation that will involve process skills acquisition for sustainable development. Okafor (2017) suggested linking the teaching of chemistry to learners' immediate environment to benefit its entrepreneurial opportunities. The use of context-based learning (CBL) pedagogy was rated highly as synonymous to the science-technology-society approach which has earned credit by the National Science Teachers Association (Holbrook, 2014). Okafor (2014), Mansour (2009), and Schwartz (2006) were of the opinion that the teaching of chemistry should enable the learners to have more control of their own learning rather than being limited to the teachers' talk-chalk and note taking. Some researchers have warned that the conventional strategy (COS) should be minimally applied during the teaching and learning process since it hinders development of conceptual understanding and problem-solving skills among students, thereby making the teaching and learning of chemistry difficult, uninteresting, and irrelevant to learners' real-life experiences (Jodi, 2010; Bennett et al., 2007; Lyons, 2006). This has led some students to conceive the idea that science is a body of knowledge to be memorized without meaningful understanding (Okafor, 2014). In spite of the dominance of conventional teaching approaches being used in the classroom, some institutes of learning teach using the $\mathrm{CBL}$ strategy to ensure that students retain the concepts taught (Holbrook, 2014).

Specifically, for this study, the new science curriculum of Nigeria emphasizes students acquiring science process skills using innovative pedagogies that should be learner-centered (Okafor, 2018; Okafor, 2014). In addition, gender was also been identified as one of the factors influencing students' acquisition of science process skills in chemistry (Okafor, 2017; Okafor, 2013). This paper, therefore, examined the effect of CBL and gender influence on secondary school students' acquisition of science process skills in chemistry.

\section{LITERATURE REVIEW}

\section{Science Process Skills}

Science process skills are part of thinking skills of the $21^{\text {st }}$ century which scientists use to build knowledge, solve 
problems, and conduct experiments (Okafor et al., 2015). Kanari and Millar (2004) explained the need to develop students' understanding in acquiring science process skills using hands-on-activities. These skills are transferable and are reflective of the scientist's behavior (Okafor et al., 2015). Ojo (2017) and Okafor (2018) demanded a revision of Nigeria's secondary school curriculum in chemistry to accommodate technological revolution in skills acquisition. Ojo (2017) outlined two major science process skills which include basic process skills and integrated process skills. Basic science process skills are skills in observing, inferring, measuring, classifying, and predicting. They provide foundation for acquisition of the higher order skills called integrated science process skills (ISPS) (Okafor, 2018). The ISPS include identifying and controlling variables, defining variables operationally, formulating hypotheses, interpreting data, and designing experiment (Ojo, 2017). ISPS are actually higher order thinking abilities built on application of learnt materials in a new situation, analyzing relationships between parts, recognizing organizational principles, synthesizing parts together to form a new whole and evaluating or judging the adequacy of program to ensure that conclusion is supported by data (Millar, 2007). Okafor (2018) explained that acquisition of basic science process skills involves students "doing science" to understand abstract concepts in chemistry. Reports of the chief examiners of West African Examination Council (WAEC) (2015) posited low performance of Northeastern secondary school students in chemistry practical examinations, which could be attributed to inadequate skills acquired (Millar, 2007). Ojo (2017) and Okafor (2018) suggested the teaching of basic and ISPS independently and interchangeably until chemistry students have mastery of every skill. There is the need to enhance the acquisition of ISPS among secondary school chemistry students for academic success and effective participation in the contemporary society.

\section{CBL and COS}

The pedagogical strategies required in teaching chemistry should be practical oriented, involving hands-on and mindin activities which could enhance problem solving, critical thinking, and science process skills acquisition (Hofstein and Kesner, 2006). Unfortunately, some of the pedagogies applied in the classrooms do not promote learners' creativity and the development of ISPS (Hofstein and Kesner, 2006). This was acknowledged by Kanari and Millar (2004) who argued that "school science" lacks the vitality of investigation, discovery, and creative inventions as well as not promoting conceptual understanding due to unproductive strategies. Holbrook (2014) suggested a context-based approach to science teaching that might promote creativity and ISPS acquisition. A study by Fensham (2009) measured the effect of context-based teaching on the development of science process skills. Respondents were asked to give written explanations on their ability to design an experiment for solving everyday problem. The results showed that respondents had proficiency in experimental design and acquired science process skills. Some researchers have observed that CBL pedagogy is geared toward developing learners' higher-order thinking skills necessary in decisionmaking and problem-solving (Jodi, 2010; Schwartz, 2006). Bennett and Lubben (2007) explained that the educators who implement context-based pedagogy during teaching and learning improve students' learning outcomes. De Jong (2008) posited that the efficacy of context-based teaching could be enhanced by the accuracy and effectiveness of materials to be utilized. The inadequate consensus on the effect of contextbased approach in the development of higher order thinking skills in chemistry could be attributed to the nature of contexts, models and how to implement the materials developed as well as the competence of the educators in material development (Holbrook, 2014; De Jong, 2008). De Jong (2008) identified five educators' competencies on effective contextualized teaching such as: Context-handling, regulation of learning, emphasis, design, and innovation. De Jong emphasized that only context-handling, regulation of learning and emphasis relate to what occurs in the classroom while the actual contexts used in developing context-based materials are critical to their efficacy to the extent that weak relationship among contexts, perception of concepts by learners and educators could influence attainment of learning outcomes.

Conversely, the teaching of chemistry in some secondary schools in Nigeria involves teacher-centered instruction, dominated by chalk and talk (Okafor, 2014). This is based on teachers' provision of few examples when solving few problems on the chalkboard, and in some cases completing the demonstration by mere explanations (Okafor, 2018). Learners in such classes listen to the teachers and write notes but hardly ask questions or make remarks (Okafor, 2018). A study conducted by Ezeliora (2002) on learners' relating chemistry knowledge to local practice of teaching was reviewed and the result showed that learners' sense of curiosity about the natural world was very low and could not relate science lessons to life experiences. McKee et al. (2007) indicated that the traditional way of teaching science involves passive learning and causes learners to be disengaged and unmotivated. Research has proven that the traditional ways of teaching science failed to sufficiently develop learners' understanding of scientific concepts (Agommuoh, 2014; Nbina, 2013). McKee et al. (2007) opined that the conventional method of teaching involves memorization of concepts which makes it difficult for the learners to comprehend concepts meaningfully. This approach of transmission of knowledge from expert sources to passive recipients has been reported to be one of the major causes of students' learning difficulty in chemistry (Okafor, 2014). Ware (2001) stated that the traditional approach of teaching chemistry might foster positive attitudes judging from the number of learners pursuing science-related careers. Bennett et al. (2007) requested the linking of science learning with learners' daily life experiences which would be facilitative than what is achieved in most traditional classrooms. This paper, therefore, determined the effect of CBL pedagogy and influence of gender on secondary school students' ISPS acquisition in chemistry. 


\section{Gender Issues in Chemistry Education}

Gender is a cultural construct that distinguishes the roles, behaviors, merits, and emotional characteristics of females and males in the society (Yusuf and Adigun, 2010). In the study of Okafor (2013) on the influence of gender in accessing chemistry education, it was observed that female chemistry students had more favorable attitudes in accessing chemistry education than males. Udeani and Okafor (2016) examined the academic career paths of young female scientists and engineers in Nigeria universities and found no inferiority complex in females in their job performance or skills application. The study of Okafor (2018) found that female chemistry students taught with integration of ideas method performed more poorly in observing and inferring skills tests than their male peers. Yusuf and Adigun (2010) reported that more female secondary school chemistry students had difficulties and misconceptions in comprehending some inorganic concepts than their counterparts. The study conducted by Okafor and Yewande (2015) on exploring students' gender showed that male students achieved higher scores than females in chemistry. Yusuf and Adigun (2010) reported that females were under-represented in chemistry even though over $50 \%$ of the population of Nigeria are women. Yusuf and Adigun (2010) also found that gender was a predictor of students' achievement in chemistry. The result of Shewu (2015) showed a non-significant difference in the achievement of male and female students taught mole concept using problem solving and lecture methods. Nsofor (2001) studied cultural impediments on women in science, technology, and mathematics education. The result showed that female students had higher interest in science than male students. It has been generally observed that gender differences exist in different areas of education from achievement, interest, attitudes, motivation, pedagogical strategies, classroom activities, course enrolment, and skills acquisition to carrier choice. These show inconclusive gender discrepancies and thus require further investigation in chemistry education.

\section{Theoretical Framework}

The theoretical framework of this study is based on Gagne (1987) theory of instructions tailored toward meeting the learners' needs. Gagne outlined five categories of learning such as verbal information, intellectual skills, cognitive strategies, attitudes, and motor skills. Gagne's theory focuses on retention and intellectual skills which stipulates that learning of new concepts or skills depends on the mastery of pre-requisite concepts. This implies that the previous knowledge determines how further knowledge could be accommodated and materials to be used must be sequentially structured. Gagne suggests that learning tasks involving intellectual skills should be organized hierarchically according to its complexity; stimulus recognition, response generation, procedure following, use of terminology, discriminations, concept formation, rule application, and problem solving. The significance of this hierarchy is to identify pre-requisites that would facilitate learning at each level. Gagne et al. (1992) outlined several steps to be used when planning and designing instructional objectives to include: Identifying the learning outcomes, each outcomes should have prerequisite knowledge or skills that must be identified, identifying the internal conditions or processes the learners have to achieve from the outcomes, identifying the external conditions or instructions needed to achieve the outcomes, specifying the learning context, recording the characteristics of the learners, selecting the media for instruction, planning to motivate learners, assessing performance, enhancing retention, and transfer to other contexts. Gagne's (1987) theory entails that science should be arranged from simple concepts for further knowledge and experiences to the complex concepts. Furthermore, the science teacher should outline specific objectives for the learning outcomes by ensuring that science curriculum contents are arranged hierarchically so that simpler contents are learned first at the lower level before complex content at higher level. This may involve logical processes of observing, describing, classifying, measuring real objects as well as other science process skills if effective pedagogies are employed. Learners, therefore, should engage their minds actively in constructing meaning from their interactions in the environment and connect them to the previous experiences in creating pattern of relationship and thinking (Okafor et al., 2015). This implies that learners should be engaged in activity-based instruction that could foster skills acquisition.

\section{Problem}

The WAEC chief examiners report indicated the need to improve secondary school chemistry students' performance in practical skills acquisition using innovative pedagogies (WAEC, 2015). Ojo (2017 and Okafor (2018) posited that this would make them lifelong learners in solving daily life problems through the application of some ISPS such as identifying and controlling variables, defining variables operationally, formulating hypotheses, interpreting data, and designing experiment. Some reasons underlying students' inadequate acquisition of ISPS were disconnectivity of school chemistry to everyday activities and industries (Okafor, 2018; Hofstein and Kesner, 2006). Some identified factors influencing students' poor acquisition of ISPS in chemistry were inadequate resources, gender, large class size, type of school, learners' unpreparedness, teacher's poor content knowledge, unproductive, and ineffective instructional strategies (Okafor, 2017; De Jong, 2008; Millar, 2007). Inadequate literature exists on how to enhance secondary school chemistry students' acquisition of ISPS through CBL (Jodi, 2010; Mansour, 2009).

This paper, therefore, examined the effect of CBL pedagogical strategy and influence of gender on secondary school students "acquisition of ISPS in chemistry across Lagos State Educational Districts of Nigeria." The two research questions which guided the study were:

1. What is the effect of CBL pedagogy and COS on secondary school students' acquisition of ISPS (experimenting, identifying and controlling variables, analyzing, and interpreting data) in chemistry? 
2. What is the influence of gender (male and female) on secondary school students' acquisition of ISPS (experimenting, identifying and controlling variables, analyzing, and interpreting data) in chemistry?

\section{METHODOLGY}

This study was a quasi-experimental, pre-test/post-test, nonrandomized research design involving intact classes subjected to CBL strategy (treatment) and COS as (control group) on a $2 \times 2$ factorial design. CBL pedagogy and COS were the independent variables while gender (males and females) was the moderating variable. The dependent variables were ISPS (experimenting; identifying and controlling variables; and analyzing and interpreting data). Education District IV was considered out of the Six Educational Districts in Lagos State because, 70\% of their public schools had adequate teaching and learning facilities. Separation technique was chosen to engender active participation of the respondents during the hands-on-activities since it is commonly practiced at home. The ISPS that measured higher order cognition such as experimenting; identifying and controlling variables; and analyzing and interpreting data skills (ANIDS) were purposively considered because students are expected to acquire these skills before completing secondary education to be self-reliant in wealth creation. The public secondary schools chosen are coeducational; have adequately equipped laboratory; teachers that hold Masters' degree in chemistry education and chemistry teachers who are favorably disposed to participate in the study. Only six public secondary schools in Education District IV met the criteria. In each of these schools, only the SSS11 arms that offer three science subjects (chemistry, physics, and biology) were selected because they were not preparing for any external examinations and had done chemistry during SS1 classes. In all, the sample population totaled 192 (113 males and 79 females) with an average age of 15. Three instruments were used in data collection which includes: CBL Manual (CBLM), COS Manual (COSM), and ISPS Test (ISPST).

\section{CBLM}

The CBLM was a student-centered manual used by chemistry teachers to engage students in the experimental (treatment) group. The role of the teacher in CBL is to lead the students through a pre-determined scenario, with a sequence of questions and hands-on activities using a series predetermined steps as shown below.

\section{CBLM}

\section{Class: SS1}

Subject: Chemistry

Topic: Separation Techniques

Behavioral Objectives: At the end of the lesson, the students should be able to:

1. Identify and explain different types of techniques for separating mixtures.

2. Carryout experiments on separation of mixtures using two techniques.
3. Assess the most useful techniques in solving daily life problem.

Previous Knowledge: The students are familiar with different mixtures for example, water and garri, rice, and beans.

Instructional Materials: Garri (cassava flakes), water, kerosene, filter paper, funnel, ink, etc.

\section{Presentation}

STEP 1: Teacher creates scenarios on the concept and ask students to explain the scenarios.

STEP 2: Students make attempt of explaining the scenarios.

STEP 3: Teacher explains the scenarios and relate them to the concept using hands-on- activities

STEP 4: Students watched the demonstrations and were allowed to undertake the hands-on activities demonstrated by the teacher.

STEP 5: Students draw out conclusions from the activities undertaken with feedbacks.

STEP 6: Students discussed the procedures, knowledge, theories, and findings involved in the hands-on activities and recorded the notes.

STEP 7: Students are assessed based on the activities they carried out.

\section{The COSM}

The COSM is a talk-chalk method in teaching separation techniques to the control group which has five steps as shown below.

\section{COSM}

Class: SS1

Subject: Chemistry

Topic: Separation Techniques

Behavioral Objectives: At the end of the lesson, the students should be able to:

1. Identify and explain different techniques for separating mixtures.

2. Carryout experiments on separation of mixtures using two techniques.

3. Assess the most useful techniques in solving daily life problem.

Previous Knowledge: The students are familiar with different mixtures, for example, water and garri, rice, and beans.

Instructional Materials: Garri (cassava flakes), water, kerosene, filter paper, funnel, ink, etc.

\section{Presentation}

The teacher introduces the topic by explaining separation techniques and listing various types of separation techniques. STEP 1: Teacher introduces separation techniques to the students.

STEP 2: Teacher lists different types of techniques for separating mixtures which include: sieving; magnetic separation; sublimation; filtration; centrifugation; floatation; evaporation; 
crystallization; fractional crystallization; separation funnel; and chromatography.

STEP 3: Teacher explains one of the techniques for separating mixtures.

STEP 4: Students listen and continuously copying notes.

STEP 5: Teacher asks students questions on the topic taught.

\section{The ISPST}

The ISPT was designed by the researcher and trial-tested on 30 students in a public school in Education District IV that did not participate in the study. The ISPST had three sections: A, $\mathrm{B}$, and $\mathrm{C}$. Section A is comprised five open-ended questions which measured Experimenting skills (EXPS). Section B had five short-answer questions which measured Identifying and Controlling Variables Skills (ICVS) while Section C had five multiple-choice objective questions with options A-D that measured ANIDS. Each question in each of the Sections was scored 2 marks with a total of 30 marks.

\section{ISPST}

\section{Gender: Male ( ) Female ( )}

Instructions: Attempt all questions in Sections $\mathrm{A}, \mathrm{B}$, and $\mathrm{C}$ on various ISPS. Your responses shall be treated confidentially.

\section{Section A: Experimenting (EXPS)}

You are provided with a mixture of three substances $\mathrm{P}, \mathrm{R}$, and $\mathrm{S}$.

$\mathrm{P}$ is a soluble salt. $\mathrm{R}$ is magnetic, has high melting point, and is insoluble. $\mathrm{S}$ is insoluble, non-magnetic and has high melting point.

You are also provided with: (i) Magnet (ii) $50 \mathrm{~cm}^{3}$ of water (iii) A funnel (iv) Filter paper (v) Two beakers

1. How would you separate and collect each of $P, R$, and $S$ ? Give your step in the right order.

2. Which of the substance will be obtained when you stir the mixture with magnet?

3. Which of the substance is collected as residue?

4. When you evaporate the filtrate, which of the substance will be gotten? What inference can you make from the experiment?

The Table below shows the physical properties of substances $\mathrm{A}, \mathrm{B}$, and $\mathrm{C}$

\begin{tabular}{|c|c|c|c|}
\hline Substance & $\begin{array}{l}\text { Melting } \\
\text { point } /{ }^{\circ} \mathrm{C}\end{array}$ & $\begin{array}{c}\text { Boiling } \\
\text { point } /{ }^{\circ} \mathrm{C}\end{array}$ & $\begin{array}{l}\text { Solubility } \\
\text { in water at } \\
25^{\circ} \mathrm{C}\end{array}$ \\
\hline A & 30 & 117 & Insoluble \\
\hline B & 31 & 160 & Insoluble \\
\hline $\mathrm{C}$ & 861 & 1200 & Soluble \\
\hline
\end{tabular}

If $\mathrm{A}$ and $\mathrm{B}$ are miscible when melted and $\mathrm{B}$ and $\mathrm{C}$ react, when heated, describe how a mixture of $\mathrm{A}, \mathrm{B}$, and $\mathrm{C}$ could be separated.

\section{Section B: ICVS}

Describe the best method that can be used to separate each of the following mixtures (identify each component that must be collected first).
1. Water and petrol

2. Benzene (b.p. $80^{\circ} \mathrm{C}$ ) and ethanol (b.p. $78^{\circ} \mathrm{C}$ )

3. Sulfur and iron fillings

4. Two liquids $\mathrm{A}$ and $\mathrm{B}$ with boiling points $92^{\circ} \mathrm{C}$ and $93.5^{\circ} \mathrm{C}$, respectively, can be best separated by .....

5. Name two substances that can undergo sublimation.

\section{Section C: ANIDS}

1. A sample of orange juice is suspected to have been contaminated with yellow dye. Which method can be used to detect the dye?
a. Distillation
b. Chromatography
c. Centrifugation
d. Evaporation

2. The separation of a mixture of calcium trioxocarbonate (iv) and sodium trioxocarbonate (iv) is mostly carried out by using the difference in their:
a. Boiling point
b. Solubilities
c. Melting point
d. Physical state

3. The proper procedure for cooling vapor in a Liebig condenser is by?
a. Pouring water on the condenser
b. Passing water through the condenser opening
c. Fanning the Liebig condenser
d. Blowing in cold air from the water inlet

4. Which one of these statements is incorrect?

a. For evaporation and distillation, pure substances have specific boiling/condensation points and melting/ freezing point.

b. For filtration, chromatography and crystallization, different substances have different solubility in the same solvent at a given temperature

c. Evaporation and boiling are the same thing

5. Blood component can be separated using:
a. Distillation
b. Chromatography
c. Centrifugation
d. Crystallization

The validity of CBLM and COSM was determined by the chemistry teachers with over 30 years teaching experience at the secondary school level and an evaluator in test development. They adjudged the teaching manuals to be valid.

The reliability of each section of ISPST was ascertained which has Cronbach alpha values of 0.80, 0.69, and 0.75, respectively, showing evidence of internal consistency. The respondents were exposed to CBLM and COSM during the beginning of third term of 2018/2019 academic session and had two periods every week. This lasted for 4 weeks. Two research assistants were trained on how to teach with CBLM. Both the experimental and control groups were given pre-test and post-test on ISPST. Data collected were analyzed using percentages, mean, mean difference, and standard deviation. 


\section{FINDINGS}

The result is presented in line with the research questions and hypothesis tested.

Table 1 shows that $58.9 \%$ accounted for males while $41.1 \%$ accounted for females. The CBL, treatment and the COS, control accounted for $60.9 \%$ and $39.1 \%$, respectively.

\section{Research Question}

(1) What is the effect of CBL pedagogy and COS on secondary school students' acquisition of ISPS (experimenting, identifying and controlling variables, analyzing, and interpreting data) in chemistry?

Table 2 considers ISPST summary whereby the respondents exposed to CBL had a mean score of 12.87 in the pre-test and a mean score of 19.29 in the post-test making a pre-test and post-test mean difference of 6.42. The control group had a mean score of 14.01 in the pre-test and a mean score of 20.26 in the post-test making a pre-test and post-test mean difference of 6.25. From these results, students taught with CBL had the highest mean difference score of 6.42 in ISPS acquisition test than those taught with COS who had lower mean difference score of 6.25 in ISPS acquisition test. Hence, CBL pedagogy had more effect than COS on students' acquisition of ISPS.

Furthermore, respondents taught with CBL strategy exposed to EXPS Test (EXPST) had the highest mean difference score of 2.29 followed by ANIDS Test (ANIDST) with a mean difference score of 2.10. Furthermore, ICVS Test (ICVST)

\begin{tabular}{lcc}
\hline \multicolumn{3}{l}{ Table 1: Demographic studies } \\
\hline Variable & Frequency & Percentage \\
\hline CBL & 117.0 & 60.9 \\
COS & 75.0 & 39.1 \\
Total & 192 & 100 \\
Male & 113.0 & 58.9 \\
Female & 79.0 & 41.1 \\
Total & 192 & 100 \\
\hline
\end{tabular}

with the mean difference score of 2.03 had the least for the same CBL pedagogy. This indicates that CBL strategy has strongest effect on EXPS acquired by secondary school chemistry students. This is followed by ANIDS which is stronger than ICVS.

In addition, respondents taught with COS exposed to ANIDST had the highest mean difference score of 2.59 followed by ICVST with the mean difference score of 1.97 while EXPST has the least mean difference score of 1.69. This shows that COS has strongest effect on ANIDS acquired by secondary school chemistry students. This is followed by ICVS which is stronger than EXPS.

\section{Research Question}

What is the influence of gender (male and female) on secondary school students' acquisition of ISPS (experimenting, identifying and controlling variables, analyzing, and interpreting data) in chemistry?

Table 3 shows that the mean difference of the female chemistry students was higher than their male counterpart on ISPS with female having mean difference score of 7.07 while male students have mean difference score of 6.52 on acquisition of ISPS respectively. This indicates that gender does have a significant influence on students' acquisition of ISPS with the female students excelling in skills acquisition.

\section{DISCUSSION}

\section{Effect of CBL and COS on secondary school students' acquisition of ISPS in chemistry}

The finding of this study shows that students exposed to CBL outperformed those exposed to COS in acquisition of ISPS. The finding corroborates with the works of Jodi (2010) and Schwartz (2006) who observed that CBL develops higher-order thinking skills in the learners such as ISPS. It also supports the assertion of Kanari and Millar (2004) who stated that "school science" lacks investigative, discovery, and creative inventions due to the application of unproductive strategies.

Table 2: Descriptive Statistics of pre and post-test scores on Acquisition of Integrated Science Process Skill (experimenting, identifying and controlling variables, analyzing and interpreting data) in chemistry when exposed to Context-Based Learning (CBL) and Conventional Strategy (COS)

\begin{tabular}{|c|c|c|c|c|c|}
\hline \multirow[t]{3}{*}{ Treatment outcomes } & \multicolumn{5}{|c|}{ Learning } \\
\hline & \multicolumn{2}{|c|}{ (Pre-test) } & \multicolumn{3}{|c|}{ (Post-test) } \\
\hline & Mean & Std. Dev. & Mean & Std. Dev. & Mean difference \\
\hline CBL EXPST & 3.94 & 1.99 & 6.23 & 1.84 & 2.29 \\
\hline ICVST & 4.361 .91 & 6.39 & 1.78 & 2.03 & \\
\hline ANIDST & 4.57 & 2.18 & 6.67 & 1.95 & 2.10 \\
\hline ISPST-Total & 12.87 & 6.08 & 19.29 & 5.57 & 6.42 \\
\hline COS EXPST & 4.74 & 2.09 & 6.43 & 1.91 & 1.69 \\
\hline ICVST & 4.90 & 2.36 & 6.87 & 1.98 & 1.97 \\
\hline ANIDST & 4.37 & 1.99 & 6.96 & 1.89 & 2.59 \\
\hline ISPST-Total & 14.01 & 6.44 & 20.26 & 5.78 & 6.25 \\
\hline
\end{tabular}

EXPST: Experimental skill test, ICVST: Identifying and controlling variables skill test, ANIDST: Analyzing and interpreting data skill test 


\begin{tabular}{|c|c|c|c|c|c|c|}
\hline \multicolumn{7}{|c|}{$\begin{array}{l}\text { Table 3: Analysis of learning outcomes scores based on } \\
\text { gender }\end{array}$} \\
\hline Gender & Learning & Mean & SD & Mean & SD & Mean \\
\hline Outcomes & & \multicolumn{2}{|c|}{ (pre-test) } & \multicolumn{2}{|c|}{ (Post-test) } & Difference \\
\hline Male & ISPS & 13.05 & 5.09 & 19.57 & 3.98 & 6.52 \\
\hline Female & ISPS & 13.17 & 4.99 & 20.24 & 4.35 & 7.07 \\
\hline
\end{tabular}

It is believed that if effective and productive materials such as CBL pedagogy are employed in the classroom, students are bound to acquire applicable skills.

More so, the students taught with CBL pedagogy acquired EXPS highly, followed by ANIDS while the least was ICVS. The strongest effect of CBL pedagogy on EXPS acquisition by secondary school chemistry students, followed by ANIDS and the least was ICVS is supported by Fensham (2009) who measured the effect of context-based teaching on the development of integrated science skills and found students proficient in experimental design. Furthermore, the finding is in line with Holbrook (2014) who posited that a context-based approach to science teaching could promote creativity and science process skills acquisition.

In addition, students taught with COS excelled in acquisition of ANIDS, followed by ICVS while EXPS was the least acquired skill. This highest effect of COS on secondary school chemistry students' acquisition of ANIDS, followed by ICVS while the least was EXPS was evidenced by McKee et al. (2007) who indicated that the traditional method of teaching science compelled learners to be unmotivated and disengaged in handson activities. The finding also corroborates with Okafor (2018) and Agommuoh (2014) who were of the view that Learners in conventional classes hardly ask questions or make remarks and have failed to adequately develop meaningful understanding of science concepts. This also supports Ware (2001) who stated that traditional method of teaching chemistry might foster positive learning outcomes to some learners willing to pursue science-related careers. However, learners' sense of curiosity about the natural world might be very low and uninteresting if $\mathrm{COS}$ is not complemented with other hands-on activities pedagogies (Okafor, 2014; Ezeliora, 2002).

\section{Influence of Gender (Male and Female) on Secondary} School Students' Acquisition of ISPS in Chemistry

The finding of this study shows influence of gender on acquisition of ISPS with the female students leading their male counterparts. This significant gender influence corroborates with the study of Okafor (2013) who posited that female chemistry students had favorable attitudes in accessing chemistry education than males. It is also in support of Udeani and Okafor (2016) who found that females do not show inferiority complex in job performance and application of skills. The study did not support Okafor (2018) who found that female chemistry students taught with integration of ideas method performed poorly in observing and inferring skills test than the male students. The finding also negates the study of
Okafor and Yewande (2015) who reported that male students achieve higher scores than the females in chemistry as well as Shewu (2015) who observed a non-significant difference in the learning outcomes of male and female students taught with problem solving and lecture methods in mole concept. This gender gap observed in favor of female chemistry students could add to a conclusive gender sensitization in the teaching and learning of chemistry in Nigeria.

\section{CONCLUSION}

The purpose of teaching chemistry requires more than acquisition of ISPS but to prepare students for academic success in the global economy driven by technological explosion. Obviously, the tasks of solving daily life problems demand development of critical thinking and science process skills through effective application of CBL pedagogy and COS. Students often ask, should they acquire science process skills? What are the importance of those skills in their lives? But skills acquired prepare them for future workforce, foster their capabilities, curiosity, and creativity in all spheres of life. Acquired skills help them to work as team players in actualizing equitable education regardless of gender stereotype in the academic sector and beyond. The potentials of CBL over COS in enhancing EXPS and ANIDS as well as COS over CBL in ANIDS and Controlling Variables Skill (ICVS) are indication that both approaches should be used interchangeably during teaching learning situation. This will equally inculcate in the students the ability to work independently and collaboratively while respecting individuals and cultural differences. Gender was identified as one of the inhibiting factors in the acquisition of ISPS in favor of female students but does not imply female domination over male or endowed capacities of females. Since gender imbalance exists in all spheres of life irrespective of the pedagogy's strategies employed, chemistry teachers should positively influence students in acquisition of integrated science skills by teaching with CBL and conventional approach interchangeably to enhance male and female chemistry students' knowledge, values, and skills creatively in Nigeria secondary school settings.

\section{RECOMMENDATIONS}

Based on the result obtained and discussed in this study, the following recommendations are made:

(1) Chemistry teachers should teach creatively and imaginatively by adapting to the dynamic teaching approach of CBL which involves hands-on activities.

(2) Teachers should efficiently blend CBL pedagogy with COS since both approaches contribute to students' acquisition of ISPS in chemistry.

(3) They should identify the acquired ISPS in the students to effectively prepare them for the future workforce development especially in experimenting, ANIDS.

(4) Curriculum developers should carefully integrate contextbased approach into the SSS chemistry curriculum to enable students acquire some of these skills consciously and unconsciously from their environment. 
(5) Principals should provide the necessary teaching facilities that are gender fair to ensure that equity and equality in learning outcomes among chemistry students are guaranteed beyond acquisition of ISPS during teaching and learning.

(6) Teachers should link the teaching of chemistry to students' everyday activities that are context-based to instill the spirit of reflective practice that fosters gender balance in ISPS acquisition in secondary school chemistry in Lagos State of Nigeria.

\section{REFERENCES}

Agommuoh, P.C. (2014). Effect of cooperative instructional strategy on secondary school students' achievement in Physics. Journal of the Nigerian Academy of Education, 10(2), 142-151.

Bennett, J., Lubben, F., \& Hogarth, S. (2007). Bringing science to life: A synthesis of the research evidence on the effects of context-based and STS approaches to science teaching science education. Science Education, 91(3), 347-370.

Bennett, J., \& Lubben, F. (2007). Context-based chemistry: The Salters approach, International Journal of Science Education, 28(09), 999-1015.

De Jong, O. (2008). Context-based chemical education: How to improve it. Chemical Education International, 8(1), 1-7.

Ezeliora, B. (2002). Relating Chemistry Teaching to Local Practice for Sustainable Science Education. Sciences Teachers' Association of Nigeria Proceedings of the $43^{\text {rd }}$ Annual Conference and Inaugural Conference of CASTME Africa. pp. 263-265.

Fensham, P.J. (2009). Real world contexts in PISA science: Implications for context-based science education. Journal of Research in Science Teaching, 46(8), 884-896.

Gagne, R. (1987). Instructional Technology Foundations. Lawrence Erlbaum Assoc.

Gagne, R., Briggs, L., \& Wager, W. (1992). Principles of Instructional Design $4^{\text {th }}$ ed. HB College Publisher.

Hofstein, A., \& Kesner, M. (2006). Industrial chemistry and school chemistry: Making chemistry studies more relevant. International Journal of Science Education, 28(9), 1017-1039.

Holbrook, J. (2014). A context-based approach to science teaching. Journal of Baltic Science Education, 13(2), 1648-3898.

Jodi, L. D. (2010) Development of conceptual understanding and problemsolving expertise in chemistry. Pakistan Journal of Education, 5(3), 205-220.

Kanari, Z., \& Millar, R. (2004). Reasoning from data: How students collect and interpret data in science investigations. Journal of Research in Science Teaching, 41(7), 748-769.

Lyons, T. (2006). Different countries, same science classes: Students' experiences of school science in their own words. International Journal of Science Education, 28(6), 591-613.

Majekodunmi, O.F. (2007) Chemistry, a Drive for National Development and Growth. An address delivered at the $30^{\text {th }}$ Annual conference of the Chemical Society of Nigeria at Abuja, September 25 $5^{\text {th }}, 2007$.

Mansour, N. (2009). Science-Technology-Society (STS): A new paradigm in science education. Bulletin of Science, Technology and Society, 29(4), 287-297.

McKee, E., Williamson, V.M., \& Ruebush, L.E. (2007). Effects of demonstration laboratory on students learning. Journal of Science Education Technology, 10(1007), 214-221.

Millar, R. (2007). Twenty first century science: Implications from the design and implementation of a scientific literacy approach in school science. International Journal of Science Education, 28(13), 230-253.

Nbina, J. B. (2013). The relative effectiveness of guided discovery and demonstration teaching methods on achievement of chemistry students of different levels of scientific literacy. Journal of Research in Education and Society, 3(2), 160-172.

Nsofor, C. (2001). Cultural impediments on women in science, technology and mathematics education. Journal of Science Teachers' Association of Nigeria, 42(2), 48-51.

Ojo, T.O. (2017). Effects of IT-Integrated Teacher Demonstration and Guided Discovery on Chemistry Students' Conceptual Knowledge, Problem Solving Skills, Acquisition of Basic Science Process Skills and $21^{\text {st }}$ Century Skills. A PhD dissertation, University of Lagos, Nigeria.

Okafor, N. (2012). Chemistry Education: A Tool for Nation Building. Guest Lecture delivered at the School of Science Education, Federal College of Education (Technical), Akoka at the National Association of Chemistry Students (NACS) Day, $8^{\text {th }}$ November.

Okafor, N. (2013). Gender influence on students' attitude in accessing chemistry education in Nigerian University. Journal of Educational Review, 6(1), 87-92.

Okafor, N. (2014). Survey of learner-centred instructional techniques used by chemistry teachers in Anambra State. Journal of Educational Thoughts, 5(10), 20-34.

Okafor, N. (2017). Pre-service education chemistry undergraduate awareness of entrepreneurial opportunities in Nigerian senior secondary school chemistry curriculum. African Journal of Science, Technology and Mathematics, 3(1), 22-32.

Okafor, N. (2018). Effects of explanations and integration of ideas pedagogy on secondary school chemistry students' acquisition of basic science process skills in Nigeria. Journal of Research in National Development, 16(2), 33-42.

Okafor, N., Yewande, R., \& Okafor, T. (2015). Investigating the $21^{\text {st }}$ Century Skills Acquired by Nigerian Secondary School Chemistry Students. Vol. 3. St. Thomas College of Teachers Education. pp. 63-74.

Okafor, N.P., \& Yewande, R.O. (2015). Motivation and self-esteem: Exploring students' gender, reasoning Levels and interest in secondary school chemistry. International Journal for Cross-Disciplinary Subjects in Education, 5(3), 2583-2589.

Schwartz, A.T. (2006). Contextualised chemistry education: The American experience. International Journal of Science Education, 28(9), 977-998.

Shewu, G. (2015). The effect of problem-solving instructional strategies on students' learning outcomes in senior secondary school chemistry. IOSR Journal of Research and Method in Education, 5(1), 10-14.

Udeani, U.N., \& Okafor, N.P. (2016). Examining the Academic Career Paths of Young Female Scientists and Engineers in Nigerian Universities. Kuwait: Proceedings of Women in Science and Technology for the Developing World (OWSDW). Fifth General Assembly and International Conference, 16-19 May.

WAEC. (2015). Chief Examiners' Report May/June. WAEC Press. West African Examination Council (WAEC).

Ware, S.A. (2001). Teaching chemistry from a societal perspective. Pure and Applied Chemistry, 73(7), 1209-1214.

Yusuf, M.A., \& Adigun, J.T. (2010). The influence of school, sex, location and type on students' academic performance. International Journal of Education Science, 2(2), 81-85. 